\title{
Risk Factors for Oral Health in Anorexia Nervosa: Comparison of a Self-Report Questionnaire and a Face-to-Face Interview
}

\author{
Hélène Rangé ${ }^{1,2, *,+} \mathbb{D}$, Alice Pallier ${ }^{1,+}$, Aminata Ali ${ }^{3,4}$, Caroline Huas ${ }^{3,4}$, Pierre Colon $5,6, \neq(\mathbb{D}$ and \\ Nathalie Godart $3,4,7, \ddagger$
}

check for

updates

Citation: Rangé, H.; Pallier, A.; Ali,

A.; Huas, C.; Colon, P.; Godart, N.

Risk Factors for Oral Health in

Anorexia Nervosa: Comparison of a Self-Report Questionnaire and a Face-to-Face Interview. Int. J. Environ. Res. Public Health 2021, 18, 4212.

https://doi.org/10.3390/

ijerph18084212

Academic Editor: Paul B. Tchounwou

Received: 12 March 2021

Accepted: 14 April 2021

Published: 16 April 2021

Publisher's Note: MDPI stays neutral with regard to jurisdictional claims in published maps and institutional affiliations.

Copyright: (c) 2021 by the authors. Licensee MDPI, Basel, Switzerland. This article is an open access article distributed under the terms and conditions of the Creative Commons Attribution (CC BY) license (https:/ / creativecommons.org/licenses/by/ $4.0 /)$.
1 Department of Periodontology, Université de Paris, UFR of Odontology, Service of Odontology, Rothschild Hospital, AP-HP, 75012 Paris, France; alicepallier@hotmail.fr

2 Université de Paris, UR 2496 Orofacial Pathologies, Imaging and Biotherapies, 92120 Montrouge, France

3 Paris-Saclay University, Paris Sud University, UFR Simone Veil, UVSQ, CESP, INSERM, 94800 Villejuif, France; aminata_ali@yahoo.fr (A.A.); caroline.huas@fsef.net (C.H.); nathalie.godart@fsef.net (N.G.)

4 Fondation Santé des Etudiants de France (FSEF), 75014 Paris, France

5 Department of Restorative Dentistry and Endodontics, Université de Paris, UFR of Odontology, Service of Odontology, Rothschild Hospital, AP-HP, 75012 Paris, France; pierre.colon@aphp.fr

6 Laboratoire Multimatériaux et Interfaces, Université Claude Bernard Lyon 1, UMR CNRS 5615, 69622 Villeurbanne, France

7 Institut Mutualiste Montsouris, 75014 Paris, France

* Correspondence: helene.range@aphp.fr; Tel.: +33-6-23-980-259

+ These authors contributed equally as first authors.

$\ddagger$ These authors contributed equally as last authors.

Abstract: Behavioral, nutritional, and local risk factors for oral health are frequent in people with anorexia nervosa. However no self-report questionnaire is available for screening in clinical practice or for research purposes. The objective of this study was to design a questionnaire to identify risk factors and symptoms of oral diseases and to test its reliability as a self-report form among people with anorexia nervosa. A 26-item questionnaire was designed based on a sound literature review performed by a group of dentists, psychiatrists, and epidemiologists specialized in the field of eating disorders. Sixty-nine anorexia nervosa inpatients (mean age $18.72 \pm 5.1$ ) were included from four specialized units. The questionnaire was first self-reported by the patients, then the same questionnaire was administrated by a dentist during a structured face-to-face interview as the gold standard. The concordance between the two forms was evaluated globally and item per item using Cohen's kappa statistical tests. The overall concordance between the self-report questionnaire and the face-to-face structured interview was $55 \%$. Of the 26 items, 19 showed significant concordance. Items relating to water intake, extracted teeth, gingival status, and oral hygiene had the best concordance (all kappa coefficients $>0.4$ ). A questionnaire that identifies risk factors and symptoms of oral diseases in anorexia nervosa was developed and tested. The 26-item form of the questionnaire (long version) is moderately reliable as a self-reported form. A short version of the questionnaire, including the 10 most reliable items, is recommended for oral risk assessment in patients with anorexia nervosa. The clinical value of the self-administered questionnaire remains to be evaluated.

Keywords: anorexia nervosa; risk factors; oral health; oral hygiene; self-report; questionnaire

\section{Introduction}

Anorexia nervosa (AN), one of the most frequent eating disorders [1] is frequently associated with oral manifestations, such as erosive tooth wear, dental caries, and periodontal diseases [2-5]. Erosive tooth wear is defined as a superficial loss of hard dental tissue due to a chemical process, without bacterial implication [6]. Erosion develops under the influence of acid ( $\mathrm{pH}$ value of 5.5), which can be of extrinsic or intrinsic origin. Intrinsic acidity results from a combination of gut disorders such as gastroesophageal reflux, 
self-induced vomiting, and merycism (rumination syndrome). Extrinsic acidity is linked to the consumption of acidic food such as fruits, and soft drinks. Dental caries result in tooth demineralization by acid production caused by the bacteria-induced fermentation of sugar. Despite a considerable decrease observed in the last few decades, the prevalence of dental caries remains a health issue of concern, both among adults and children, and it is particularly high among patients with AN [3]. Periodontal diseases are chronic multifactorial inflammatory diseases associated with dysbiotic dental plaque, including gingivitis and periodontitis [7,8]. Gingival recessions are defined as an apical shift of the gingival margin caused by different conditions/pathologies, leading to root surface exposure to the oral environment [9]. Dental caries and periodontal diseases share common risk factors related to carbohydrate intake, poor oral hygiene, and hyposalivation [10]. Oral diseases lead to pain, dysfunction, and aesthetic issues having an adverse impact on the self-esteem and quality of life in people with eating disorders [11]. Moreover, they visit their dentist less frequently than the general population [12-14]. Survey studies have identified several barriers to prevention and dental care, both in patients with eating disorders (dental fear, denial), and in oral health care providers (lack of training and network) [14-18]. Therefore, self-screening of oral risk factors and symptoms using a questionnaire should be part of the routine healthcare circuit for people with AN [19]. However, as far as we know, there is no easy to handle questionnaire available to evaluate risk factors and symptoms of oral diseases to be used by AN patients themselves. The objectives of the study were: (1) to design such a questionnaire and, (2) to test its reliability as a self-report questionnaire (SRQform) in a sample of AN inpatients by cross-referencing the results with those obtained using the same instrument administrated as a hetero-report questionnaire (Q-form) by a specialized dentist.

\section{Materials and Methods}

\subsection{Context of the Study}

A senior multidisciplinary expert group in eating disorders involved in the Fédération Française Anorexie Boulimie, collaborated on a trans-disciplinary clinical study, entitled EVHAN (evaluation of hospitalization for anorexia nervosa; Eudract number: 2007-A0111053; registered in clinical trials). The study protocol was approved by the Ile-de-France III Ethics Committee and the CNIL (Commission nationale de l'informatique et des libertés).

The inclusion criteria were: (1) age between 8 to 65 years old; (2) hospitalized for AN (DSM-IV-TR criteria) [20], and therefore unable to be treated otherwise because of their somatic state (body mass index $<15 \mathrm{~kg} / \mathrm{m}^{2}$ ) or their mental state; (3) written informed consent of their parents for minors and adults living with their parents; (4) written informed consent of the patient obtained; and (5) being affiliated with social security. The exclusion criteria were: (1) patients with a comorbidity that may impact the oral health, like diabetes mellitus and inflammatory bowel disease; (2) not being proficient in the French language.

\subsection{Questionnaire Design}

The questionnaire was drawn up by a group of specialized dentists, psychiatrists, and epidemiologists from the literature related to risk factors for oral diseases in eating disorders patients and related to erosive tooth wear in the general population [12,13,21-26]. A comprehensive questionnaire was designed following the structure of a standard dental examination divided into 7 themes: dental history, lifestyle, nutritional status, oral hygiene, salivary flow, gingival status, and dental status (Table 1). 
Table 1. The 26-item questionnaire for screening oral risk factors and symptoms in anorexia nervosa.

\begin{tabular}{|c|c|c|}
\hline Themes & Questions & Response' Choices \\
\hline \multirow{4}{*}{$\begin{array}{l}\text { Dental History } \\
\text { (2 questions) }\end{array}$} & Q 1: How often did you have dental care? & Occasionally or Frequently \\
\hline & Q2: What was the reason for dental treatment? & Scaling or Emergency or Check-up or \\
\hline & Q3: Do you participate in sporting activities? & Yes or No \\
\hline & Q4: For how long? & $\begin{array}{c}\text { Less than } 1 \text { year or Between } 1 \text { to } 4 \text { years } \\
\text { or More than } 4 \text { years }\end{array}$ \\
\hline \multirow[t]{7}{*}{$\begin{array}{c}\text { Lifestyle } \\
\text { (8 questions) }\end{array}$} & Q5: How often? & $\begin{array}{c}\text { Daily or On a regular basis or } \\
\text { Occasionally }\end{array}$ \\
\hline & Q6: What type of sporting activity do you practice? & $\begin{array}{l}\text { Swimming-pool sport or Endurance sport } \\
\text { or Dancing or Other sporting activity }\end{array}$ \\
\hline & Q7: Are you used to monitoring your weight? & Daily or Occasionally or Never \\
\hline & Q8: Have you noticed changes in your weight? & Yes or No \\
\hline & Q9: In what direction? & Weight increase or Weight decrease? \\
\hline & Q10: Are you satisfied with your body appearance? & Yes or No \\
\hline & Q11: How many meals do you have per day? & 1 or 2 or 3 or $>3$ \\
\hline \multirow{6}{*}{$\begin{array}{l}\text { Nutritional } \\
\text { status } \\
\text { (12 questions) }\end{array}$} & Q12: How often do you eat snack? & $\begin{array}{c}\text { Daily or On a regular basis, Occasionally } \\
\text { or Never }\end{array}$ \\
\hline & Q13: Do you have the habit of fasting? & $\begin{array}{l}\text { Frequently or periodically or } \\
\text { Occasionally or Never }\end{array}$ \\
\hline & Q14: Are you used to drinking sodas? & Yes or No \\
\hline & Q15: Are you used to drinking fruit juice? & Yes or No \\
\hline & Q16: Are you used to eating sweets? & Yes or No \\
\hline & Q17: How much water do you drink per day? & $\begin{array}{l}\text { Less than a bottle }(1.5 \mathrm{~L}) \text { or Close to a } \\
\text { bottle }(1.5 \mathrm{~L}) \text { or More than a bottle }(1.5 \mathrm{~L})\end{array}$ \\
\hline \multirow{2}{*}{$\begin{array}{l}\text { Oral hygiene } \\
\text { (4 questions) }\end{array}$} & Q18: How many times per day do you brush your teeth? & 1 or 2 or 3 or $>3$ \\
\hline & Q19: What type of toothbrush do you use? & $\begin{array}{l}\text { Soft bristles or Medium bristles or Hard } \\
\text { bristles }\end{array}$ \\
\hline \multirow{4}{*}{$\begin{array}{l}\text { Salivary flow } \\
\text { (3 questions) } \\
\text { Gingival status } \\
\text { (3 questions) }\end{array}$} & Q20: Do you often have a dry mouth? & Yes or No \\
\hline & Q21: Do you have slimy saliva? & Yes or No \\
\hline & Q22: Do you have bleeding gums after toothbrushing? & Yes or No \\
\hline & Q23: Have you noticed that your teeth are getting longer? & Yes or No \\
\hline \multirow{3}{*}{$\begin{array}{l}\text { Dental status } \\
\text { (4 questions) }\end{array}$} & Q24: Have you ever had any extracted teeth (except wisdom teeth)? & Yes or No \\
\hline & Q25: Do you suffer from over-sensitive teeth? & Yes or No \\
\hline & Q26: Do you think that the enamel of your teeth is damaged? & Yes or No \\
\hline
\end{tabular}

The 26-item SRQ-form was pre-tested in a sample of 20 consecutive individuals with AN attending a dental visit at Rothschild Hospital (Paris, France) to assess the comprehensibility of the items. Pilot patients were then face-to-face interviewed by the dental examiner $(\mathrm{PC})$ about the overall questionnaire comprehensibility and clarity. No major revision of the questionnaire was requested following the cognitive evaluation.

\subsection{Questionnaire Evaluation}

The reliability evaluation of the SRQ-form was tested against the Q-form delivered during a structured face-to face interview, following a previously published methodology $[27,28]$. The patients filled in the SRQ-form at the end of their eating disorder hospitalization in four Parisian centers (Institut Mutualiste Montsouris, Sainte-Anne Hospital, Maison de Solenn, Robert Debré Hospital, and Paul Brousse Hospital). Then a dental structured face-to-face interview and clinical examination were organized using the same questionnaire filled in by a specialized dentist (PC) at the Rothschild Hospital.

\subsection{Statistical Analysis}

A concordance analysis was conducted between data from the SRQ-form and the Q-form. Cohen's kappa coefficient was used to assess agreement between the two methods of administration of the questionnaire: self-administered and hetero-administered. Kappa coefficients of $>0.6,0.6-0.41,0.4-0.21$, and $\leq 0.2$ were considered substantial, moderate, fair, and slight, respectively, according to Landis and Koch's criteria [29]. A p-value 
less than 0.05 was considered statistically significant. The statistical software SPPS 20.0 (IBM, Armonk, NY, USA) was used.

\section{Results}

\subsection{Description of the Participants}

Sixty-nine female consecutive inpatients agreed to participate and were included in the present study. The mean age of the AN inpatients was 18.72 ( $\mathrm{SD}=5.1$ ), and $64.1 \%$ were under 18 years old. Concerning the diagnosis of $\mathrm{AN}, 50.9 \%$ of the inpatients presented a restrictive type and $49.1 \%$ a binging-purging type. The mean duration of AN was 3.83 years $(\mathrm{SD}=6.13)$. The mean $\mathrm{BMI}$ of the study sample was $14.25(\mathrm{SD}=1.51)$. In the interviewed inpatients, dry mouth, gum bleeding after toothbrushing, and tooth hypersensitivity were reported by $33.3 \%, 47.3 \%$, and $37.5 \%$, respectively.

\subsection{Reliability Evaluation of the Self-Report Questionnaire Form}

All patients agreed to answer the SRQ-form, however 5 questionnaires were not completed (missing data). The remaining 64 inpatients agreed to continue with the study, and completed the Q-form administered by the specialized dentist after their hospitalization. The results of the concordance analysis are described in Table 2.

Table 2. Concordance analysis for each item between the self-report questionnaire and the face-to-face interview.

\begin{tabular}{|c|c|c|c|c|c|}
\hline Items & Response' Choices & $\begin{array}{c}\text { With the } \\
\text { Self-Report } \\
\text { Questionnaire } \\
n(\%)\end{array}$ & $\begin{array}{c}\text { During the } \\
\text { Face-to-Face } \\
\text { Interview } \\
n(\%)\end{array}$ & $\begin{array}{c}\text { Kappa } \\
\text { Coefficient }\end{array}$ & $p$-Value \\
\hline \multirow{3}{*}{$\begin{array}{l}\text { Q 1: How often did you } \\
\text { have dental care? }\end{array}$} & Occasionally & $49(87.5 \%)$ & $49(87.5 \%)$ & \multirow{3}{*}{0.184} & \multirow{3}{*}{0.169} \\
\hline & Frequently & $7(12.5 \%)$ & $7(12.5 \%)$ & & \\
\hline & Scaling & $11(20.8 \%)$ & $4(7.5 \%)$ & & \\
\hline \multirow{3}{*}{$\begin{array}{c}\text { Q2: What was the reason for } \\
\text { dental treatment? }\end{array}$} & Emergency & $1(1.9 \%)$ & $3(5.7 \%)$ & \multirow{3}{*}{0.184} & \multirow{3}{*}{0.042} \\
\hline & Check-up & $33(62.3 \%)$ & $36(67.9 \%)$ & & \\
\hline & Ongoing treatment & $8(15.1 \%)$ & $10(18.9 \%)$ & & \\
\hline \multirow{3}{*}{$\begin{array}{l}\text { Q3: Do you participate in } \\
\text { sporting activities? }\end{array}$} & No & $22(38.6 \%)$ & $8(14 \%)$ & \multirow{3}{*}{0.244} & \multirow{3}{*}{0.023} \\
\hline & Yes & $35(61.4 \%)$ & $49(86 \%)$ & & \\
\hline & Less than 1 year & $4(13.8 \%)$ & $3(10.3 \%)$ & & \\
\hline \multirow[t]{3}{*}{ Q4: For how long? } & Between 1 to 4 years & $11(37.9 \%)$ & $10(34.5 \%)$ & \multirow[t]{2}{*}{0.473} & \multirow{3}{*}{0.001} \\
\hline & More than 4 years & $14(48.3 \%)$ & $16(55.2 \%)$ & & \\
\hline & Daily & $4(13.8 \%)$ & $4(13.8 \%)$ & \multirow{3}{*}{0.451} & \\
\hline \multirow{3}{*}{ Q5: How often? } & On a regular basis & $24(82.8 \%)$ & $21(72.4 \%)$ & & \multirow{2}{*}{0.001} \\
\hline & Occasionally & $1(3.4 \%)$ & $4(13.8 \%)$ & & \\
\hline & Swimming-pool sport & $4(11.8 \%)$ & $10(29.4 \%)$ & \multirow{4}{*}{0.474} & \multirow{4}{*}{$<0.001$} \\
\hline \multirow{3}{*}{$\begin{array}{l}\text { Q6: What type of sporting } \\
\text { activity do you practice? }\end{array}$} & Endurance sport & $5(14.7 \%)$ & $4(11.8 \%)$ & & \\
\hline & Dancing & $10(29.4 \%)$ & $9(26.5 \%)$ & & \\
\hline & Other sportive activity & $15(44.1 \%)$ & $11(32.4 \%)$ & & \\
\hline \multirow{3}{*}{$\begin{array}{l}\text { Q7: Are you used to } \\
\text { monitoring your weight? }\end{array}$} & Daily & $23(41.8 \%)$ & $30(54.5 \%)$ & \multirow{3}{*}{0.274} & \multirow{3}{*}{0.027} \\
\hline & Occasionally & $31(56.4 \%)$ & $24(43.6 \%)$ & & \\
\hline & Never & $1(1.8 \%)$ & $1(1.8 \%)$ & & \\
\hline \multirow{2}{*}{$\begin{array}{l}\text { Q8: Have you noticed } \\
\text { changes in your weight? }\end{array}$} & No & $12(21.1 \%)$ & $4(7 \%)$ & \multirow[b]{2}{*}{0.022} & \multirow[b]{2}{*}{0.841} \\
\hline & Yes & $45(78.9 \%)$ & $53(93 \%)$ & & \\
\hline \multirow{2}{*}{ Q9: In what direction? } & Weight increase & $33(78.6 \%)$ & $31(73.8 \%)$ & \multirow{2}{*}{0.215} & \multirow{2}{*}{0.16} \\
\hline & Weight decrease & $9(21.4 \%)$ & $11(26.2 \%)$ & & \\
\hline \multirow{2}{*}{$\begin{array}{l}\text { Q10: Are you satisfied with } \\
\text { your body appearance? }\end{array}$} & No & $29(52.7 \%)$ & $31(56.4 \%)$ & \multirow{2}{*}{0.487} & \\
\hline & Yes & $26(47.3 \%)$ & $24(43.6 \%)$ & & $<0.001$ \\
\hline & 2 & $3(5.3 \%)$ & $2(3.5 \%)$ & & \\
\hline Q11: How many meals do & 3 & $22(38.6 \%)$ & $21(36.8 \%)$ & 0.36 & 0.002 \\
\hline & $>3$ & $32(56.1 \%)$ & $34(59.6 \%)$ & & \\
\hline & Daily & $1(1.8 \%)$ & $2(3.5 \%)$ & & \\
\hline Q12: How often do you & On a regular basis & $2(3.5 \%)$ & $2(3.5 \%)$ & & \\
\hline eat snack? & Occasionally & $16(28.1 \%)$ & $13(22.8 \%)$ & 0.285 & 0.009 \\
\hline & Never & $38(66.7 \%)$ & $40(70.2 \%)$ & & \\
\hline
\end{tabular}


Table 2. Cont.

\begin{tabular}{|c|c|c|c|c|c|}
\hline Items & Response' Choices & $\begin{array}{c}\text { With the } \\
\text { Self-Report } \\
\text { Questionnaire } \\
n(\%)\end{array}$ & $\begin{array}{c}\text { During the } \\
\text { Face-to-Face } \\
\text { Interview } \\
n(\%)\end{array}$ & $\begin{array}{c}\text { Kappa } \\
\text { Coefficient }\end{array}$ & $p$-Value \\
\hline \multirow{4}{*}{$\begin{array}{l}\text { Q13: Do you have the habit } \\
\text { of fasting? }\end{array}$} & Frequently & $3(55.5 \%)$ & $2(3.6 \%)$ & \multirow{4}{*}{0.257} & \multirow{4}{*}{0.004} \\
\hline & Periodically & $5(9.1 \%)$ & $4(7.3 \%)$ & & \\
\hline & Occasionally & $6(10.9 \%)$ & $14(25.5 \%)$ & & \\
\hline & Never & $41(74.5 \%)$ & $35(63.6 \%)$ & & \\
\hline \multirow{2}{*}{$\begin{array}{l}\text { Q14: Are you used to } \\
\text { drinking sodas? }\end{array}$} & No & $52(91.2 \%)$ & $17(29.8 \%)$ & \multirow[b]{2}{*}{0.026} & \multirow[b]{2}{*}{0.615} \\
\hline & Yes & $5(8.8 \%)$ & $40(70.2 \%)$ & & \\
\hline \multirow{2}{*}{$\begin{array}{l}\text { Q15: Are you used to } \\
\text { drinking fruit juice? }\end{array}$} & No & $29(50.9 \%)$ & $7(12.3 \%)$ & \multirow{2}{*}{0.238} & \multirow{2}{*}{0.006} \\
\hline & Yes & $28(49.1 \%)$ & $50(87.7 \%)$ & & \\
\hline \multirow{2}{*}{$\begin{array}{l}\text { Q16: Are you used to } \\
\text { eating sweets? }\end{array}$} & No & $47(83.9 \%)$ & $14(25 \%)$ & \multirow[b]{2}{*}{0.12} & \multirow[b]{2}{*}{0.059} \\
\hline & Yes & $9(16.1 \%)$ & $42(75 \%)$ & & \\
\hline \multirow{3}{*}{$\begin{array}{l}\text { Q17: How much water do } \\
\text { you drink per day? }\end{array}$} & $<1.5 \mathrm{~L}$ & $22(38.6 \%)$ & $22(38.6 \%)$ & \multirow{3}{*}{0.655} & \multirow{3}{*}{$<0.001$} \\
\hline & around $1.5 \mathrm{~L}$ & $30(52.6 \%)$ & $31(54.4 \%)$ & & \\
\hline & $>1.5 \mathrm{~L}$ & $5(8.8 \%)$ & $4(7 \%)$ & & \\
\hline \multirow{4}{*}{$\begin{array}{c}\text { Q18: How many times per } \\
\text { day do you brush } \\
\text { your teeth? }\end{array}$} & 1 & $3(5.3 \%)$ & $2(3.5 \%)$ & \multirow{4}{*}{0.466} & \multirow{4}{*}{$<0.001$} \\
\hline & 2 & $28(49.1 \%)$ & $33(57.9 \%)$ & & \\
\hline & 3 & $20(35.1 \%)$ & $19(33.3 \%)$ & & \\
\hline & $>3$ & $6(10.5 \%)$ & $3(5.3 \%)$ & & \\
\hline \multirow{3}{*}{$\begin{array}{l}\text { Q19: What type of } \\
\text { toothbrush do you use? }\end{array}$} & Soft bristles & $30(54.5 \%)$ & $20(36.4 \%)$ & \multirow{3}{*}{0.43} & \multirow{3}{*}{$<0.001$} \\
\hline & Medium bristles & $23(41.8 \%)$ & $34(61.8 \%)$ & & \\
\hline & Hard bristles & $2(3.6 \%)$ & $1(1.8 \%)$ & & \\
\hline \multirow{2}{*}{$\begin{array}{c}\text { Q20: Do you often have a } \\
\text { dry mouth? }\end{array}$} & No & $42(73.7 \%)$ & $38(66.7 \%)$ & \multirow{2}{*}{0.25} & \multirow{2}{*}{0.056} \\
\hline & Yes & $15(26.3 \%)$ & $19(33.3 \%)$ & & \\
\hline \multirow{2}{*}{$\begin{array}{l}\text { Q21: Do you have } \\
\text { slimy saliva? }\end{array}$} & No & $51(91.1 \%)$ & $53(94.6 \%)$ & \multirow[b]{2}{*}{0.072} & \multirow{2}{*}{0.577} \\
\hline & Yes & $5(8.9 \%)$ & $3(5.4 \%)$ & & \\
\hline \multirow{2}{*}{$\begin{array}{l}\text { Q22: Do you have bleeding } \\
\text { gums after toothbrushing? }\end{array}$} & No & $39(70.9 \%)$ & $29(52.7 \%)$ & \multirow{2}{*}{0.479} & $<0001$ \\
\hline & Yes & $16(29.1 \%)$ & $26(47.3 \%)$ & & $<0.001$ \\
\hline $\begin{array}{l}\text { Q23: Have you noticed that } \\
\text { your teeth are }\end{array}$ & No & $49(86 \%)$ & $53(93 \%)$ & 0.448 & $<0.001$ \\
\hline getting longer? & Yes & $8(14 \%)$ & $4(7 \%)$ & & \\
\hline Q24: Have you ever had any & No & $52(92.9 \%)$ & $51(91.1 \%)$ & 0638 & $<0001$ \\
\hline $\begin{array}{l}\text { extracted teeth (except } \\
\text { wisdom teeth)? }\end{array}$ & Yes & $4(7.1 \%)$ & $5(8.9 \%)$ & 0.638 & $<0.001$ \\
\hline Q25: Do you suffer from & No & $36(64.3 \%)$ & $35(62.5 \%)$ & 0.346 & 0.01 \\
\hline over-sensitive teeth? & Yes & $20(35.7 \%)$ & $21(37.5 \%)$ & 0.346 & 0.01 \\
\hline Q26: Do you think that the & No & $48(85.7 \%)$ & $47(83.9 \%)$ & 0.376 & 0.005 \\
\hline $\begin{array}{l}\text { enamel of your teeth } \\
\text { is damaged? }\end{array}$ & Yes & $8(14.3 \%)$ & $9(16.1 \%)$ & $0.3 / 0$ & 0.005 \\
\hline
\end{tabular}

From the 26 items under scrutiny, 19 were significantly concordant with a $p$-value $<0.05$. No questions from the theme related to salivary flow retrieved statistical agreement. The overall agreement of the questionnaire was fair at $55.55 \%$. The agreement significance varied from excellent to poor (100\% to $12 \%$ ), depending on the item (data not shown). The best agreements between the SRQ-form and the Q-form were obtained for the items related to water intake (kappa coefficient $=0.655)$ and extracted teeth (kappa coefficient $=0.638)$. Eight items presented moderate agreement (between 0.41-0.6), 4 from the lifestyle theme: sport activity/body appearance, 2 from the oral hygiene theme: amount of toothbrushing/type of toothbrush, and 2 from the gingival status theme: gum bleeding/root exposure. Nutritional status items (except for water intake) and dental status showed fair agreement (Table 3). 
Table 3. Reliability of the questionnaire's items according to Landis and Koch [29].

\begin{tabular}{ccc}
\hline Values of the Kappa Coefficient & Meaning of the Agreement & Items \\
\hline$\leq 0.2$ & slight & Q2 \\
$0.21-0.4$ & fair & Q3, Q7, Q11, Q12, Q13, Q15, Q25, Q26 \\
$0.41-0.6$ & moderate & Q4, Q5, Q6, Q10, Q18, Q19, Q22, Q23 \\
$>0.6$ & substantial & Q17, Q24 \\
\hline
\end{tabular}

\section{Discussion}

Identifying oral health status in people with $\mathrm{AN}$ is essential to provide resources to patients for prevention and dental care. Being able to collect this information will become increasingly important for psychiatrists and physicians in a multidisciplinary approach to eating disorder treatment. Therefore, a questionnaire for self-screening of oral risk factors and symptoms in people with severe AN was developed and its reliability was tested. Qualitative data covering seven themes depicted factors influencing oral health status: dental history, lifestyle, nutritional status, oral hygiene, salivary flow, gingival status, and dental hygiene were identified. In the present study, gum bleeding after toothbrushing was the most frequently reported oral health symptom, with $47.3 \%$ among AN inpatients. Tooth hypersensitivity was also frequently reported by $37.5 \%$ of the patients. A case control study in eating disorders patients, including both AN and bulimia nervosa, published similar results, with $41 \%$ reporting dental problems [21]. However, only $33 \%$ among AN inpatients in our study self-reported to feel a dry mouth, in comparison to the $52 \%$ and $92 \%$ previously reported $[21,24]$. The discrepancy observed between our results and those from Viera Esteves and coworkers may be explained by the study population (AN inpatients only versus a mixt cohort of mainly bulimia nervosa patients with few anorexia nervosa patients). A methodological difference should also be highlighted because they used a specialized five-item questionnaire developed for evaluating subjective feeling of mouth dryness (xerostomia) [30], whereas two questions where used in the present questionnaire.

As far as we know, there has been no study that compared the reliability of a selfreport questionnaire on oral health in eating disorders with a face-to-face interview as a gold standard. Prior observational studies constructed various questionnaires, used during face-to-face interviews only $[12,13,21,22]$. The recently published questionnaire in research from Norway and Sweden comprising 196 questions is too long for widespread usage as a self-report questionnaire for screening oral health status in people with AN at medical centres and educational settings. It has been shown that people respond less readily to long questionnaires than short ones [31]. However, in our study, all the related oral health risk factors (behavioral and nutritional) and symptoms (salivary flow, gingival status, and dental status) were addressed in only 26 questions. The overall observed agreement between the SRQ-form compared with the face-to-face structured interview was relatively good. Irrational results regarding oral health perception and attitudes in people with eating disorders have been reported in the literature [14,16,32]. Indeed, denial is a frequent symptom in AN patients, especially among young people. Patients are known to give unreliable answers and/or deliberately omit talking about their somatic and psychological symptoms [32]. Some symptoms are perceived as shameful and therefore denied. In the present study, questions with the lowest agreements were those dealing with the purging/binge eating habits and the dental status. Consequently, the questions used to investigate these themes might be removed from a proposal of a short 10-item version of the questionnaire focused on the most reliable questions (Table 4). In addition, one of the most reliable self-reported items in our study, i.e., gingival bleeding, has been found to be a valid approach to determining gingival status in the general population and there is no reason to suspect that this would not hold true in the AN population [33]. 
Table 4. Proposal for a short version of the self-report questionnaire based on the 10 most reliable items compared to the face-to-face interview.

\begin{tabular}{cll}
\hline Theme & Items & Questions \\
\hline \multirow{3}{*}{ Lifestyle } & Q short 1 (Q long-version 4) & For how long do you practice sporting activity? \\
& Q short 2 (Q long-version 5) & How often do you practice sporting activity? \\
& Q short 3 (Q long-version 6) & What type of sporting activity do you practice? \\
Nutritional status & Q short 4 (Q long-version 10) & Are you satisfied with your body appearance? \\
Oral hygiene & Q short 5 (Q long-version 17) & How much water do you drink per day? \\
Gingival status & Q short 7 (Q long-version 18) & How many times per day do you brush your teeth? \\
Dental status & Q short 8 (Q long-version 22) & What type of toothbrush do you use? \\
& Q short 9 (Q long-version 23) & Do you have bleeding gums after toothbrushing? \\
& Q short 10 (Q long-version 24) & Have you noticed that your teeth are getting longer? \\
\hline
\end{tabular}

Some limitations need to be acknowledged in our study. The young mean age of the patients limited the severity of the dental and periodontal manifestations, which increases with the duration of the eating disorder. However, this study focused on a sample of severely ill patients (hospitalized, with a very low BMI), among whom complications are frequent. There are many difficulties in populations with eating disorders in accessing a professional dental examination, mainly because of denial (patients) and the lack of awareness of oral health (physicians, psychiatrists). The questionnaire covers eating behaviors, physical activities, and dental symptoms that are not investigated routinely through dental/medical history. Despite the value of the questionnaire relying on its simplicity for self-administration by patients, the clinical implications and relevance for dental management need to be assessed. In addition, the questionnaire remains to be validated against clinical parameters for oral symptoms (salivary flow, gingival status, and dental status). Despite these limitations, this study developed the first reliable and easy to handle self-report questionnaire for evaluating risk factors and symptoms of oral disorders in anorexia nervosa. The results of this study suggest that a short version of the questionnaire would have value as a screening tool to benefit the AN patient's awareness regarding the oral impact of their eating disorder and to initiate a conservation with the oral health professional for adequate prevention and treatment.

\section{Conclusions}

This study aimed to develop a specific questionnaire to assess oral risk factors and symptoms in anorexia nervosa. The hetero-administered form was designed as a guideline for dentists who are not trained in eating disorder care. On top of that, the short version (10-item) of the questionnaire has an additional value as a self-report form to prepare for a dental examination, and which should be part of the healthcare circuit of people with AN. Finally, this questionnaire could also be used for epidemiological studies in AN patients in order to identify the most frequent risk factors observed and associations with their mental and somatic clinical profile.

Author Contributions: Conceptualization, A.P., A.A., P.C. and N.G.; Methodology, A.P., A.A., P.C. and N.G.; Validation, A.P., A.A., P.C. and N.G.; Formal Analysis, A.P., A.A., P.C. and N.G.; Investigation, A.P., A.A., P.C. and N.G.; Resources, P.C. and N.G.; Data Curation, H.R., A.P. and A.A.; Writing-Original Draft Preparation, H.R., A.P., A.A. and C.H.; Writing-Review \& Editing, H.R., A.P., A.A., C.H., P.C. and N.G.; Supervision, P.C. and N.G.; Project Administration, N.G.; Funding Acquisition, N.G. All authors have read and agreed to the published version of the manuscript.

Funding: The EVHAN study (Evaluation of Hospitalization for Anorexia Nervosa) was funded by grants from the French Ministry of Health (PHRCN 2007, 2011 AOM11197; ANR Jeune chercheur, Bourse de thèse Eiffel), and from CNAM-TS, Fondation de France, Fondation MGEN, EHESP, AP-HP, CIFRE, and Contrats d'interface INSERM. The funders had no role in the study design, the data collection and analysis, the decision to publish, or the preparation of the manuscript. 
Institutional Review Board Statement: All procedures performed relating to studies involving human participants were in accordance with the ethical standards of the institutional and/or national research committee and with the 1964 Helsinki declaration and its later amendments or comparable ethical standards. (Eudract number: 2007-A01110-53; registered in clinical trials).

Informed Consent Statement: Informed consent was obtained from all individual participants included in the study.

Data Availability Statement: The data presented in this study are available on request from the corresponding author.

Acknowledgments: The authors would like to thank Sophie Criquillon and Brigitte Remy for their contribution to the conception of the patient evaluation, and TC for the English editing. This work arises from the EVHAN Group: Nathalie Godart, Sylvie Berthoz, Jeanne Duclos, Lama Mattar, Hélène Roux, Marie-Raphaële Thiébaud, Christophe Lalanne, Sarah Vibert, Tamara Hubert, Annaig Courty, Damien Ringuenet, Jean-Pierre Benoit, Corinne Blanchet, Marie-Rose Moro, Laura Bignami, Clémentine Nordon, Frédéric Rouillon, Solange Cook, Catherine Doyen, Marie-Christine Mouren Siméoni, Priscille Gerardin, Sylvie Lebecq, Marc-Antoine Podlipski, Claire Gayet, Malaika Lasfar, Marc Delorme, Xavier Pommereau, Stéphanie Bioulac, Manuel Bouvard, Jennifer Carrere, Karine Doncieux, Sophie Faucher, Catherine Fayollet, Amélie Prexl, Stéphane Billard, François Lang, Virginie Mourier-Soleillant, Régine Greiner, Aurélia Gay, Guy Carrot, Sylvain Lambert, Morgane Rousselet, Ludovic Placé, Jean-Luc Venisse, Marie Bronnec, Bruno Falissard, Christophe Genolini, Christine Hassler, Jean-Marc Tréluyer, Olivier Chacornac, Maryline Delattre, Nellie Moulopo, Christelle Turuban, and Christelle Auger.

Conflicts of Interest: The authors have no conflict of interest to report.

\section{References}

1. American Psychiatric Association. DSM-5 Task Force, Diagnostic and Statistical Manual of Mental Disorders: DSM-5, 5th ed.; American Psychiatric Association: Washington, DC, USA, 2013; p. 947.

2. Hermont, A.P.; Oliveira, P.A.; Martins, C.C.; Paiva, S.M.; Pordeus, I.A.; Auad, S.M. Tooth erosion and eating disorders: A systematic review and meta-analysis. PLoS ONE 2014, 9, e111123. [CrossRef] [PubMed]

3. Kisely, S.; Baghaie, H.; Lalloo, R.; Johnson, N.W. Association between poor oral health and eating disorders: Systematic review and meta-analysis. Br. J. Psychiatry 2015, 207, 299-305. [CrossRef]

4. Pallier, A.; Karimova, A.; Boillot, A.; Colon, P.; Ringuenet, D.; Bouchard, P.; Rangé, H. Dental and periodontal health in adults with eating disorders: A case-control study. J. Dent. 2019, 84, 55-59. [CrossRef] [PubMed]

5. Touyz, S.W.; Liew, V.P.; Tseng, P.; Frisken, K.; Williams, H.; Beumont, P.J. Oral and dental complications in dieting disorders. Int. J. Eat. Disord. 1993, 14, 341-347. [CrossRef]

6. Bartlett, D.; Ganss, C.; Lussi, A. Basic Erosive Wear Examination (BEWE): A new scoring system for scientific and clinical needs. Clin. Oral. Investig. 2008, 12 (Suppl. 1), S65-S68. [CrossRef] [PubMed]

7. Chapple, I.L.C.; Mealey, B.L.; Van Dyke, T.E.; Bartold, P.M.; Dommisch, H.; Eickholz, P.; Geisinger, M.L.; Genco, R.J.; Glogauer, M.; Goldstein, M.; et al. Periodontal health and gingival diseases and conditions on an intact and a reduced periodontium: Consensus report of workgroup 1 of the 2017 World Workshop on the Classification of Periodontal and Peri-Implant Diseases and Conditions. J. Clin. Periodontol. 2018, 45 (Suppl. 20), S68-S77. [CrossRef]

8. Papapanou, P.N.; Sanz, M.; Buduneli, N.; Dietrich, T.; Feres, M.; Fine, D.H.; Flemmig, T.F.; Garcia, R.; Giannobile, W.V.; Graziani, F.; et al. Periodontitis: Consensus report of workgroup 2 of the 2017 World Workshop on the Classification of Periodontal and Peri-Implant Diseases and Conditions. J. Clin. Periodontol. 2018, 45 (Suppl. 20), S162-S170. [CrossRef] [PubMed]

9. Jepsen, S.; Caton, J.G.; Albandar, J.M.; Bissada, N.F.; Bouchard, P.; Cortellini, P.; Demirel, K.; de Sanctis, M.; Ercoli, C.; Fan, J.; et al. Periodontal manifestations of systemic diseases and developmental and acquired conditions: Consensus report of workgroup 3 of the 2017 World Workshop on the Classification of Periodontal and Peri-Implant Diseases and Conditions. J. Clin. Periodontol. 2018, 45 (Suppl. 20), S219-S229. [CrossRef]

10. Chapple, I.L.; Bouchard, P.; Cagetti, M.G.; Campus, G.; Carra, M.C.; Cocco, F.; Nibali, L.; Hujoel, P.; Laine, M.L.; Lingstrom, P.; et al. Interaction of lifestyle, behaviour or systemic diseases with dental caries and periodontal diseases: Consensus report of group 2 of the joint EFP/ORCA workshop on the boundaries between caries and periodontal diseases. J. Clin. Periodontol. 2017, 44 (Suppl. 18), S39-S51. [CrossRef]

11. Chiba, F.Y.; Sumida, D.H.; Moimaz, S.A.S.; Chaves Neto, A.H.; Nakamune, A.; Garbin, A.J.I.; Garbin, C.A.S. Periodontal condition, changes in salivary biochemical parameters, and oral health-related quality of life in patients with anorexia and bulimia nervosa. J. Periodontol. 2019, 90, 1423-1430. [CrossRef]

12. Johansson, A.K.; Norring, C.; Unell, L.; Johansson, A. Diet and behavioral habits related to oral health in eating disorder patients: A matched case-control study. J. Eat. Disord. 2020, 8, 7. [CrossRef] [PubMed] 
13. Ohrn, R.; Enzell, K.; Angmar-Månsson, B. Oral status of 81 subjects with eating disorders. Eur. J. Oral. Sci. 1999, 107, 157-163. [CrossRef] [PubMed]

14. Willumsen, T.; Graugaard, P.K. Dental fear, regularity of dental attendance and subjective evaluation of dental erosion in women with eating disorders. Eur. J. Oral. Sci. 2005, 113, 297-302. [CrossRef]

15. Conviser, J.H.; Fisher, S.D.; Mitchell, K.B. Oral care behavior after purging in a sample of women with bulimia nervosa. J. Am. Dent. Assoc. 2014, 145, 352-354. [CrossRef]

16. Dynesen, A.W.; Gehrt, C.A.; Klinker, S.E.; Christensen, L.B. Eating disorders: Experiences of and attitudes toward oral health and oral health behavior. Eur. J. Oral. Sci. 2018, 126, 500-506. [CrossRef] [PubMed]

17. DiGioacchino, R.F.; Keenan, M.F.; Sargent, R. Assessment of dental practitioners in the secondary and tertiary prevention of eating disorders. Eat. Behav. 2000, 1, 79-91. [CrossRef]

18. Debate, D.R.; Tedesco, L.A. Increasing dentists' capacity for secondary prevention of eating disorders: Identification of training, network, and professional contingencies. J. Dent. Educ 2006, 70, 1066-1075. [CrossRef] [PubMed]

19. HAS. Anorexia Nervosa: Management. Clinical Practice Guidelines. 2011. Available online: https://www.has-sante.fr/upload/ docs/application/pdf/2013-05/anorexia_nervosa_guidelines_2013-05-15_16-34-42_589.pdf (accessed on 15 April 2021).

20. American Psychiatric Association. Diagnostic and Statistical Manual of Mental Disorders, 4th ed.; Text Revision (DSM-IV-TR) ed.; American Psychiatric Association: Arlington, VA, USA, 2000.

21. Johansson, A.K.; Norring, C.; Unell, L.; Johansson, A. Eating disorders and oral health: A matched case-control study. Eur. J. Oral. Sci. 2012, 120, 61-68. [CrossRef] [PubMed]

22. Lourenço, M.; Azevedo, Á.; Brandão, I.; Gomes, P.S. Orofacial manifestations in outpatients with anorexia nervosa and bulimia nervosa focusing on the vomiting behavior. Clin. Oral. Investig. 2018, 22, 1915-1922. [CrossRef]

23. Lussi, A.; Hellwig, E.; Zero, D.; Jaeggi, T. Erosive tooth wear: Diagnosis, risk factors and prevention. Am. J. Dent. 2006, 19, 319-325.

24. Vieira Esteves, C.; Gushiken de Campos, W.; Gallo, R.T.; Ebling Artes, G.; Shimabukuro, N.; Witzel, A.L.; Lemos, C.A. Oral profile of eating disorders patients: Case series. Spec. Care Dentist. 2019, 39, 572-577. [CrossRef] [PubMed]

25. Lussi, A.; Schaffner, M.; Hotz, P.; Suter, P. Dental erosion in a population of Swiss adults. Community Dent. Oral Epidemiol. 1991, 19, 286-290. [CrossRef] [PubMed]

26. Lussi, A.; Jaeggi, T.; Zero, D. The role of diet in the aetiology of dental erosion. Caries Res. 2004, 38 (Suppl. 1), 34-44. [CrossRef] [PubMed]

27. Steffen, M.W.; Murad, M.H.; Hays, J.T.; Newcomb, R.D.; Molella, R.G.; Cha, S.S.; Hagen, P.T. Self-report of tobacco use status: Comparison of paper-based questionnaire, online questionnaire, and direct face-to-face interview-Implications for meaningful use. Popul. Health Manag. 2014, 17, 185-189. [CrossRef]

28. Dill, D.L.; Chu, J.A.; Grob, M.C.; Eisen, S.V. The reliability of abuse history reports: A comparison of two inquiry formats. Compr. Psychiatry 1991, 32, 166-169. [CrossRef]

29. Landis, R.J.; Koch, G.G. The Measurement of Observer Agreement for Categorical Data. Biometrics 1977, 33, 159-174. [CrossRef]

30. Delli, K.; Spijkervet, F.K.; Kroese, F.G.; Bootsma, H.; Vissink, A. Xerostomia. Monogr. Oral. Sci. 2014, $24,109-125$.

31. Rolstad, S.; Adler, J.; Ryden, A. Response burden and questionnaire length: Is shorter better? A review and meta-analysis. Value Health 2011, 14, 1101-1108. [CrossRef]

32. Couturier, L.J.; Lock, J. Denial and minimization in adolescents with anorexia nervosa. Int. J. Eat. Disord. 2006, 39, 212-216. [CrossRef]

33. Veynachter, T.; Orti, V.; Moulis, E.; Rousseau, H.; Thilly, N.; Anagnostou, F.; Jeanne, S.; Bisson, C. Prevalence and Associated Factors of Self-Reported Gingival Bleeding: A Multicenter Study in France. Int. J. Environ. Res. Public Health 2020, 17, 8563. [CrossRef] 